\title{
PENGAWASAN ISI ULANG AIR TERHADAP GALON BERMEREK DI DISPERINDAG KOTA MALANG: Kajian Hukum Positif Dan Hukum Islam
}

\author{
M. Aris Ardhian C. \\ Fakultas Syariah Universitas Islam Negeri Maulana Malik Ibrahim Malang \\ Email: arisardhian2@gmail.com
}

\section{Abstract}

The purpose of this research is to know how the supervisory Disperindag against water refill using a branded gallon in Malang, according to the study of the positive law in force and also according to Islamic law. This research is also called with the research field research. The results showed that Disperindag yet to carry out surveillance of Malang against charging process water use branded a gallon. This is contrary to the positive law and Islamic law in Indonesia, which mentions that the Disperindag must do an oversight process goes by the effort of filling water in the city of Malang

Tujuan penelitian ini adalah mengetahui bagaimana pelaksanaan pengawasan Disperindag terhadap isi ulang air menggunakan galon bermerek di Kota Malang menurut kajian Hukum Positifyang berlaku indonesia dan juga menurut Hukum Islam. Penelitian ini disebut juga dengan penelitian field research. Hasil penelitian menunjukkan bahwa Disperindag Kota Malang belum melaksanakan pengawasan terhadap proses pengisian air menggunakan galon bermerek. Hal ini bertentangan dengan Hukum Positif dan Hukum Islam yang berlaku di Indonesia, yang menyebutkan bahwa Disperindag haruslah melakukan suatu pengawasan terhadap proses berjalannya usaha pengisian air yang ada di Kota Malang

Keywords: supervisory, branded a gallon, merk, Islamic law

\section{Pendahuluan}

Air bersih yang layak minum saat ini semakin langka dijumpai, di perkotaan. Sungai-sungai yang menjadi sumbernya sudah tercemar berbagai macam limbah, 
mulai dari buangan sampah organik rumah tangga hingga limbah beracun dari industri. Air tanah pun sudah tidak aman dijadikan bahan air minum karena telah terkontaminasi rembesan dari tangki septictank maupun air permukaan yang tercemar, akhirnya dicari cara menghindarkan konsumen dari akibat negatif pemakaian barang dan atau jasa. ${ }^{1}$ Selain itu kebutuhan akan tersedianya air bersih bagi masyarakat merupakan harga mati, maka tidak mengherankan jika usaha air minum dalam kemasan (AMDK) yang menggunakan mata air dari pegunungan banyak dikonsumsi.

Kebutuhan masyarakat akan ketersediaan air yang layak minum dalam arti berkualitas dan terjamin dari segi kesehatan juga tinggi, demikian juga kebutuhan masyarakat terhadap sesuatu yang praktis dan instant menjadikan bisnis Air Minum Dalam Kemasan (AMDK) semakin berkembang pesat. Perusahaan yang menggarap bisnis AMDK pun semakin banyak dan terus melakukan ekspansi untuk memperluas jaringan pasar produk-produknya.

Namun dalam perkembangannya, harga AMDK dari berbagai merek yang terus meningkat membuat konsumen mencari alternatif baru yang murah misalnya dengan memanfaatkan air minum isi ulang, peluang ini menjadikan bisnis air minum isi ulang memiliki pangsa pasar sendiri. Dengan meningkatnya kebutuhan masyarakat akan air minum dan adanya keuntungan yang menjanjikan dalam bisnis air minum isi ulang ini, maka bermunculanlah depot air minum isi ulang yang dalam pelaksanaan usaha jual beli air minum isi ulang banyak terjadi pelanggaran terutama mengenai penggunaan galon bermerek milik pengusaha AMDK yang merek atau logonya sudah dilindungi oleh Pemerintah karena telah terdaftar.

Berbicara mengenai hak milik intelektual, sebenarnya berbicara tentang pelaksanaan dari sebuah hukum Hak Kekayaan Intelektual pada dasarnya merupakan suatu hak yang timbul sebagai hasil kemampuan intelektual manusia yang menghasilkan suatu proses atau produk yang bermanfaat bagi umat manusia dalam berbagai bidang seperti ilmu pengetahuan, seni, sastra, invensi di bidang teknologi. ${ }^{2}$ Berdasarkan latar belakang tersebut, maka menjadi hal yang menarik untuk mengkaji praktek pengawasan pengisian ulang terhadap galon bermerek di Kota Malang baik melalui perspektif hukum positif ataupun hukum Islam.

1 Abdul Halim Barkatullah, Hak-Hak Konsumen, (Bandung: Nusa Media, 2010), h.48

2 Budi Santoso, Pengantar HKI dan Audit HKI untuk Perusahaan, (Semarang: Pustaka Magister, 2009), h. 3. 


\section{Metode Penelitian}

Jenis penelitian yang dipilih dalam penulisan ini adalah penelitian lapangan (field research), yaitu penelitian yang data maupun informasinya bersumber dari lapangan yang digali secara intensif yang disertai dengan analisa dan pengujian kembali atas semua data atau informasi yang telah dikumpulkan. Dalam penelitian ini yang dijadikan objek penelitian adalah di Disperindag Kota Malang dan juga wawancara secara mendalam terhadap staf Disperindag dan juga terhadap sepuluh pemilik usaha isi ulang air minum di Kota Malang.

Tempat penelitian adalah tempat yang digunakan dalam melakukan penelitian untuk memperoleh data yang diinginkan. Penelitian ini berlokasi di Kantor Disperindag Kota Malang yang beralamatkan di Jl. Mayjend Sungkono, Kedungkandang, Buring, Arjowinangun, Kota Malang, Jawa Timur 65136. Indonesia

\section{Pembahasan}

Pengawasan menurut Saragih adalah sebagai berikut: "Pengawasan adalah kegiatan manajer yang mengusahakan agar pekerjaan-pekerjaan terlaksana sesuai dengan rencana yang ditetapkan dan atau hasil yang dikehendaki”."

Sedangkan Pengawasan menurut Sujatmo mengungkapkan bahwa: "Pengawasan adalah segala usaha atau kegiatan untuk mengetahui dan menilai kenyataan yang sebenarnya mengenai pelaksanaan tugas atau kegiatan, apakah sesuai dengan yang semestinya atau tidak". ${ }^{4}$

Terwujudnya tujuan yang dikehendaki sebenarnya tidak lain merupakan tujuan dari pengawasan. Sebab setiap kegiatan pada dasarnya selalu mempunyai tujuan tertentu. Oleh karena itu pengawasan mutlak diperlukan dalam usaha pencapaian suatu tujuan. Menurut Situmorang dan Juhir maksud pengawasan adalah untuk :

1. Mengetahui jalannya pekerjaan, apakah lancar atau tidak

2. Memperbaiki kesalahan-kesalahan yang dibuat oleh pegawai dan mengadakan pencegahan agar tidak terulang kembali kesalahan-kesalahan yang sama atau timbulnya kesalahan yang baru.

3. Mengetahui apakah penggunaan budget yang telah ditetapkan dalam rencana terarah kepada sasarannya dan sesuai dengan yang telah direncanakan.

4. Mengetahui pelaksanaan kerja sesuai dengan program (fase tingkat pelaksanaan)

3 Saragih. Sistem Pengawasan dalam Organisasi, (Jakarta: Rajawali Press. 1982), h. 88.

4 Sujatmo., Beberapa Pengertian Tentang Pengawasan, (Jakarta: Ghalia Indonesia, 1983.), h. 19.

5 Victor M. Situmorang, Jusuf Juhir, Aspek Hukum Pengawasan Melekat Dalam Lingkungan Aparatur Pemerintah. (Jakarta : Rineka Cipta, 1994.), h.22. 
seperti yang telah ditentukan dalam planning atau tidak.

5. Mengetahui hasil pekerjaan dibandingkan dengan yang telah ditetapkan dalam planning, yaitu standard.

\section{Tinjauan Umum Tentang Perlindungan Hak Merek}

Merek sebagai salah satu wujud karya intelektual memiliki peranan penting bagi kelancaran dan peningkatan perdagangan barang atau jasa dalam kegiatan perdagangan dan investasi. Merek (dengan "brand image"- nya) dapat memenuhi kebutuhan konsumen akan tanda pengenal atau daya pembeda yang teramat penting dan merupakan jaminan kualitas produk atau jasa dalam suasana persaingan bebas. Oleh karena itu Merek adalah aset ekonomi bagi pemiliknya, baik perorangan maupun perusahaan (badan hukum) yang dapat menghasilkan keuntungan besar, tentunya bila didayagunakan dengan memperhatikan aspek bisnis dan proses manajemen yang baik. Demikian pentingnya peranan Merek ini, maka terhadapnya dilekatkan perlindungan hukum, yakni sebagai obyek terhadapnya terkait hak-hak perseorangan atau badan hukum.

Hak merek merupakan hak kekayaan industri yang dilindungi oleh sistem HKI. Merek adalah tanda yang berupa gambar, nama, kata, hurufhuruf, angka-angka, susunan warna, atau kombinasi dari unsur-unsur tersebut yang memiliki daya pembeda dan digunakan dalam kegiatan perdagangan barang atau jasa (UUM). Pengaturan merek di Indonesia pertama kali diatur melalui Undang- Undang Nomor 19 Tahun 1992 dan telah diubah dengan UndangUndang Nomor 14 Tahun 1997 tentang Perubahan atas Undang- Undang Nomor 19 Tahun 1992 tentang Merek.Setelah ratifikasi keanggotaan WTO pada tahun 1994, selanjutnya pengaturan merek dilakukan penyesuaian dengan TRIPs melalui Undang-Undang Nomor 15 Tahun 2001 tentang Merek.

Dalam hukum Islam, Merek merupakkan bagian dari hak milik pribadi, bukan hak milik umum. Merek merupakan bagian dari Hak Atas Kekayaan Intelektual. Permasalahan hak milik Intelektual senantiasa berkembang seiring perkembangan Ilmu Pengetahuan dan teknologi.

Jika ditinjau dari perspektif hukum Islam, memakai hak orang lain tanpa seijin pemiliknya tentunya tidak dibenarkan, karena hak cipta merupakan harta (property) bagi si pemiliknya. Islam selalu menganjurkan untuk selalu menghargai milik orang lain dan hasil jerih payah seseorang. Sebagaimana yang tercantum dalam Surat an-Nisa' ayat 29:

"Hai orang-orangyang beriman, janganlab kamu saling memakan harta sesamamu dengan jalan yang batil, kecuali den- gan jalan perniagaan yang berlaku dengan suka sama-suka di antara kamu. Dan janganlah kamu membunuh dirimu se sunggubnya 
Allah adalah Maha Penyayang kepadamu"(QS an Nisa': 29).

Menurut pendapat peneliti, jika dalil di atas dikaitkan dengan dalil kemanfaatan ilmu, maka menggunakan hak cipta orang lain tanpa ijin, bukan suatu yang batil. Seseorang diperkenankan menggandakan sebuah hasil karya tanpa ijin, jika penggandaan tidak ditujukan untuk tujuan mengambil keuntungan (kepentingan ekonomis). Adakalanya di sebuah daerah, apabila untuk mendapatkan suatu buku yang langka dan terbatas jumlahnya, padahal dibutuhkan manfaatnya untuk tujuan pendidikan, tentunya menggandakan buku dengan jumlah terbatas tanpa seijin pencipta atau pemegang hak cipta hukumnya diperbolehkan. Hal ini sesuai dengan penggunaan wajar (fair dealing) yang diatur di dalam pasal 15 UUHC.

Dalam buku karangan Khoirul Hidayah yang berjudul Hukum HKI(Hak Kekayaan Intelektual) di Indonesia Kajian Undang-undang \& Integrasi Islam menyebutkan beberapa pendapat para ulama terkait pelanggaran hak cipta: ${ }^{6}$

1. Dr. Fathi al-Duraini menjelaskan: 'Mayoritas ulama dari kalangan mazhab Maliki, Syafi'i dan Hanbali berpendapat bahwa hak cipta atas ciptaan yang orisinal dan manfaat tergolong harta berharga sebagaimana benda jika boleh dimanfaatkan secara syara' (hukum Islam)"

2. Wahbah al-Zuhaili berkenaan dengan hak kepengarangan (haqq al talif), salah satu hak cipta menegaskan: "Berdasarkan hal (bahwa hak kepengarangan adalah hak yang dilindungi oleh syara' (hukum Islam) atas dasar qaid- ah istishlah) tersebut, mencetak ulang atau mengcopi buku(tanpa izin yang sah) dipandang sebagai pelanggaran atau kejahatan terhadap hak pengarang; dalam arti bahwa perbuatan tersebut adalah kemaksiatan yang menimbulkan dosa dalam pandangan Syara' dan merupakan pencurian yang mengharuskan ganti rugi terhadap hak pengarang atas naskah yang dicetak secara melanggar dan zalim, serta menimbulkan kerugian moril yang menimpanya"

3. Keputusan Fatwa MUI Nomor: 1/MUNAS VILMUL5/2005 Tentang Perlindungan Hak Kekayaan Intelektual (HK) Fatwa MUI mengeluarkan ketentuan hukum:

a. Dalam hukum Islam, HKI dipandang sebagai salah satu huquq maliyyah (hak kekayaan) yang mendapat perlindungan hukum (mashun) sebagaimana mal (kekayaan)

b. HKI yang mendapat perlindungan hukum lslam adalah HKl yang tidak bertentangan dengan hukum Islam.

c. HKI dapat dijadikan obyek akad(al-maaud'alaih), baik akad muuawadhah

6 Khoirul Hidayah, Hukum HKI (Hak Kekayaan Intelektual) di Indonesia Kajian Undang-undang \& Integrasi Islam, Cet. 2, (Malang: UIN-Maliki Press. 2013). h. 59-61 
(pertukaran, komersial), maupun akad tabarruat (non komersial), serta dapat diwaqafkan dan diwariskan.

4. Setiap bentuk pelanggaran terhadap HKI, termasuk namun tidak terbatas pada menggunakan, mengungkapkan, membuat, memakai, menjual, mengimpor, mengekspor, mengedarkan, menyerahkan, menyediakan, mengumumkan, memperbanyak, menjiplak, memalsu, membajak HKI milik orang lain secara tanpa hak merupakan kedzaliman dan hukumnya adalah haram.

Dalam hukum Islam Merek bagian dari hak milik pribadi, bukan hak milik umum. Hak milik pribadi merupakan hak milik syara' pada individu untuk memanfaatkan sesuatu, baik berupa benda maupun jasa. Islam menghargai dan menghormati hak milik pribadi. Karenanya Islam memberikan sanksi hukum yang cukup berat terhadap siapa saja yang berani melanggar hak milik pribadi atau menyerobot hak orang lain ${ }^{7}$

\section{Pengawasan Isi Ulang Air di Disperindag Kota Malang}

Pengawasan pada dasarnya diarahkan sepenuhnya untuk menghindari adanya kemungkinan penyelewengan aau penyimpangan atas tujuan yang akan dicapai melalui pengawasan diharapkandapat membantu melaksanakan kebijakan yang telah ditetapkan untuk mencapai tujuan yang telah direncanakan seara efektif dan efisien. Bahkan, melalui pengawasan tercipta suatu aktivitas yang berkaitan erat denan penentuan atau evaluasi mengenai sejauhmana pelaksanaan kerja sudah dilaksanakan. Pengawasan juga dapat mendeteksi sejauhmana kebijakan pimpinan dijalankan dan sampai sejauhmana penyimpangan yang terjadi dalam pelaksanan kerja tersebut. ${ }^{8}$

Konsep pengawasan demikian sebenarnya menunjukkan pengawasan dianggap sebagai bentuk pemeriksaan atau pengontrolan dari pihak yang lebih atas kepda pihak di bawahnya. "dalam ilmu manajemen, pengwasan ditempatkan sebagai tahapan terakhir dari fungsi manajemen ". Dari segi manajerial, pengawasan mengandung makna pula sebagai: "pengmatan atas pelaksanaan seluruh kegiatan unit organisasi yang diperiksa untuk menjamin agar seluruh seluruh kegiatan unit organisasi yang diperiksa unyuk menjamin agar seluruh pekerjaan yang sedang dilaksanakan sesuai dengan rencana dan peraturan". ${ }^{9}$

Adapun beberapa peraturan pemerintah yang terkait dengan pengaturan

7 Luluk Atirotu Zahroh, AHKAM Jurnal Hukum Islam, Volume 08, Nomor 01, Juli 2006, Rekontruksi Metode Fiqih Hubungan Antar Agama, Majelis Syuro Muslimin Indonesia (Kajian Fiqih Siyasah), Jurusan Syariah, Sekolah Tinggi Agama Islam Negeri Tulungagung, h. 80

8 Sujamto, Aspek-Aspek Pengawasan, (Jakarta: Ghalia, 1999) h. 45

9 M. Manullang, Dasar-Dasar Manajemen, (Yogyakarta: UGM University Press, 2005) h. 107. 
pengawasan isi ulang air galon bermerek di Indonesia adalah sebagai berikut:

a. Undang-undang No. 15 Tahun 2001 Tentang Merek

b. Keputusan Menteri Peridustrian dan Perdagangan Republik Indonesia Nomor : 651/MPP/10/2004 Tentang Persyaratan Teknis Depot Air Minum Isi Ulang Perdagangannya

c. Keputusan Menteri Peridustrian dan Perdagangan Republik Indonesia Nomor : 705/MPP/Kep/11/2003 Tentang Persyaratan Teknis Industri Air Minum Dalam Kemasan dan Perdagangannya

d. Peraturan Daerah Kota Malang No. 56 Tahun 2008 Tentang Uraian Tugas Pokok, Fungsi dan Tata Kerja Dinas Perindustrian dan Perdagangan Pemerintah Kota Malang.

Berdasarkan hasil wawancara yang dilakukan terhadap disperindag ${ }^{10}$ diperoleh data bahwa Disperindag Kota Malang selama ini belum melakukan pengawasan terhadap praktek usaha air minum isi ulang, hal ini dijelaskan salah satu faktornya adalah karena keterbatasan jumlah staf yang tersedia. Data yang diperoleh di lapangan juga terhadap 10 pemilik usaha depot air isi ulang di Kota Malang menyatakan bahwa para pelaku usaha belum sepenuhnya mengerti tentang peraturan yang berlaku dalam praktek usaha air minum isi ulang, bahkan ada yang belum mengerti tentang Disperindag itu sendiri. ${ }^{11} \mathrm{Hal}$ ini menunjukkan bahwa masih banyak pelaku usaha air minum isi ulang ini yang belum mengetahui tentang aturan-aturan yang berlaku dalam praktek usaha air isi ulang ini. Selain itu untuk pelaku usaha air minum isi ulang juga belum mengerti secara keseluruhan tentang peraturan-peraturan yang ada, seperti yang dituturkan langsung oleh ketiga pelaku usaha depot air minum isi ulang. Dalam hal ini Dinas Perindustrian dan Perdagangan mempunyai kewajiban untuk melakukan sosialisasi secara khusus untuk menjelaskan tentang peraturan peraturan yang berlaku bagi pelaku usaha air minum isi ulang.

\section{Pengawasan terhadap Praktek Usaha Air Isi Ulang Menurut Maslahah Mursalah}

Dengan telah diterbitkannya Surat Keputusan Menteri Perindustrian dan Perdagangan No. 651/MPP/10/2004 Tentang Persyaratan Teknis Depot Air Minum Isi Ulang dan Perdagangannya pada tanggal 18 Oktober 2004 dan Keputusan Menteri Kesehatan Nomor 907/MENKES/SK/VII/2002 Tentang Syarat dan Kualitas Air Minum, maka perlindungan hukum bagi konsumen pengguna air

10 Wawancara staf Disperindag. 10 Desember 2016. Disperindag Kota Malang

11 Wawancara, 12-20 Desember 2016 di Kota Malang 
minum isi ulang lebih terjamin, ${ }^{12}$ hal tersebut tampak dalam ketentuan Pasal 7 Surat Keputusan Menteri Perindustrian dan Perdagangan No.651/MPP/10/2004 Tentang Persyaratan Teknis Depot Air Minum Isi Ulang dan Perdagangannya.

1. Depot Air Minum hanya diperbolehkan menjual produknya secara langsung kepada konsumen dilokasi Depot dengan cara mengisi wadah yang dibawa oleh konsumen atau disediakan Depot.

2. Depot Air Minum dilarang memiliki "stock' produk air minum dalam wadah yang siap dijual.

3. Depot Air minum hanya diperbolehkan menyediakan wadah tidak bermerek atau wadah polos.

4. Depot Air Minum wajib memeriksa wadah yang dibawa oleh konsumen dan dilarang mengisi wadah yang tidak layak pakai.

5. Depot Air minum harus melakukan pembilasan dan atau pencucian dan atau sanitasi wadah dan dilakukan dengan cara yang benar.

6. Tutup wadah yang disediakan oleh Depot Air Minum harus polos/ tidak bermerek.

7. Depot Air Minum tidak diperbolehkan memasang segel/shrink wrap’ pada wadah

Dalam ayat kedua juga disebutkan bahwa para pelaku usaha dilarang untuk menyediakan stok produk dalam wadah siap jual, jika melihat dalam realita yang ada, maka sebagaian besar pelaku usaha tidak melakukan apa yang disebutkan dalam ayat kedua ini, yang berarti bahwa sebagian besar pelaku usaha depot air isi ulang ini menyediakan stok bagi para konsumen, dan yang pasti stok tersebut bukan dalam wadah yang polos kemudian diperjelas lagi dengan ayat keenam bahwa tutup wadah juga harus polos dan juga ayat ketujuh tidak diperbolehkan memasang segel shrink atau wrap, dan yang disebutkan dalam ayat keempat, yaitu ayat yang melarang menggunakan galon yang bermerek, peraturan ini sejalan dengan Fatwa MUI tentang Perlindungan Hak Kekayaan Intelektual, yang berati jelas bahwa islam memberikan perlindungan hukum bagi pemilik merek.

Dalam Surat Keputusan Menteri Perindustrian dan Perdagangan No. 651/ MPP/10/2004 Tentang Persyaratan Teknis Depot Air Minum Isi Ulang dan Perdagangannya menjelaskan peraturan peraturan yang sejalan dengan Fatwa MUINomor: 1/MUNAS VILMUL5/2005 Tentang Perlindungan Hak Kekayaan Intelektual ( $\mathrm{HK})$, dimana aturan aturan tersebut memberikan perlindungan hukum bagi pemilik merek. Dan juga pasal diatas menyebutkan tentang peraturan dalam proses pengisian air minum isi ulang, peraturan ini khusus mengatur wadah air 1210 Ari Purwadi, Telaah Singkat Tentang Undang-Undang Perlindungan Konsumen, Jurnal Hukum dan Keadilan, Vol. 3, No. 3. 2000: 116-126, h. 16. 
minum yang dikeluarkan oleh Menteri Perindustrian dan Perdagangan, dalam peraturan ini jelas terlihat bahwa penggunaan galon air milik pihak lain oleh pelaku bisnis air minum isi ulang adalah suatu pelanggaran. Kemudian dijelaskan juga dalam Pasal 9 ayat (3) Keputusan Menteri Perindustrian dan Perdagangan No.705/MPP/Kep/11/2003 tentang Persyaratan Teknis Industri Air Minum Dalam Kemasan dan Perdagangannya menyatakan bahwa galon air (kemasan) suatu merek air minum isi ulang hanya boleh diisi ulang oleh perusahaan pemilik merek yang bersangkutan. Selanjutnya dalam pengawasannya disebutkan dalam Pasal 9 Surat Keputusan Menteri Perindustrian dan Perdagangan No. 651/ MPP/10/2004 Tentang Persyaratan Teknis Depot Air Minum Isi Ulang dan Perdagangannya.

1. Kewenangan pengawasan terhadap Depot Air Minum sebagaimana dimaksud dalam pasal 8 ayat (1) dilaksanakan oleh Menteri yang dilimpahkan kepada :

a. Gubernur untuk melaksanakan koordinasi dalam pelaksanaan pengawasan di daerah Propinsi sesuai wilayah kerjanya.

b. Gubernur DKI Jakarta untuk melaksanakan pengawasan di wilayah DKI Jakarta.

c. Bupati/Walikota kecuali DKI Jakarta untuk melaksanakan pengawasan di Daerah Kabupaten/Kota sesuai wilayah kerjanya.

2. Gubernur dan Bupati/Walikota sebagaimana dimaksud dalam ayat (1) hurufb dan c dalam melaksanakan tugas pengawasan melimpahkan kewenangannya kepada Kepala Unit Kerja sesuai dengan lingkup tugas dan tanggung jawabnya.

3. Biaya yang berkaitan dengan pelaksanaan pengawasan sebagaimana dimaksud ayat (1) dibebankan kepada Anggaran Pendapatan dan Belanja Daerah (APBD) masing-masing Pemerintah Daerah Propinsi dan Kabupaten/Kota.

Dalam pengawasan terhadap depot air minum isi ulang dijelaskan dalam dalam Pasal 9 ayat (1) dan (2) bahwa yang berhak melaksanakan pengawasan di Kota Malang adalah Walikota, kemudian walikota melimpahkan kewenangan pengawasan kepada Kepala Unit Kerja, dalam hal ini sesuai dengan ruanglingkup tugas pengawasan oleh unit kerja disusun dalam Peraturan Daerah Kota Malang Nomor 56 Tahun 2008 pasal 3.

Peraturan Proses Pengisian Air Isi Ulang sangat jelas dijelaskan dalam Kepmenperindag No.651/MPP/10/2004 Pasal 7 Tentang Persyaratan Teknis Depot Air Minum Isi Ulang dan Perdagangannya dan Kepmenperindag No.705/ MPP/Kep/11/2003 Pasal 9 tentang Persyaratan Teknis Industri Air Minum Dalam Kemasan dan Perdagangannya. Untuk berjalannya peraturan peraturan yang telah dibuat maka butuh akan adanya pengawasan agar tidak adanya pelanggaran- 
pelanggaran yang dilakukan oleh pihak pihak tertentu, dalam hal ini khususnya oleh depot pengisian air isi ulang.

Dengan berbagai dasar hukum yang telah disebutkan maka Dinas Perindustrian Kota Malang berhak melakukan pengawasan terhadap bidang perdagangan, seperti yang dijelaskan dalam Peraturan Walikota Malang Nomor 56 Tahun 2008 Pasal 3 tentang tugas dan fungsi Dinas Perindustrian dan Perdagangan Kota Malang. Pengawasan pengisian ulang galon bermerek menyangkut tentang hak merek, karena hak merek merupakan suatu hal yang sangat dilindungi dalam Islam. Dalam hukum Islam, Merek merupakkan bagian dari hak milik pribadi, bukan hak milik umum. Merek merupakan bagian dari Hak Atas Kekayaan Intelektual. Permasalahan hak milik Intelektual senantiasa berkembang seiring perkembangan Ilmu Pengetahuan dan teknologi.

Jika ditinjau dari perspektif hukum Islam, memakai hak orang lain tanpa seijin pemiliknya tentunya tidak dibenarkan, karena hak cipta merupakan harta bagi si pemiliknya. Islam selalu menganjurkan untuk selalu menghargai milik orang lain dan hasil jerih payah seseorang. Sebagaimana yang tercantum dalam Surat an-Nisa' ayat 29:

"Hai orang-orangyang beriman, janganlab kamu saling memakan harta sesamamu dengan jalan yang batil, kecuali den- gan jalan perniagaan yang berlaku dengan suka sama-suka di antara kamu. Dan janganlah kamu membunub dirimu se sungguhnya Allah adalab Maha Penyayang kepadamu"(QS an Nisa': 29).

Dalam fatwa MUINomor: 1/MUNAS VILMUL5/2005 Tentang Perlindungan Hak Kekayaan Intelektual (HK) Fatwa MUI mengeluarkan ketentuan hukum:

1. Dalam hukum Islam, HKI dipandang sebagai salah satu buquq maliyyah (hak kekayaan) yang mendapat perlindungan hukum (mashun) sebagaimana mal (kekayaan)

2. HKI yang mendapat perlindungan hukum lslam adalah $\mathrm{HKl}$ yang tidak bertentangan dengan hukum Islam.

3. HKI dapat dijadikan obyek akad(al-maaud'alaih), baik akad munawadhah (pertukaran, komersial), maupun akad tabarruat (non komersial), serta dapat diwaqafkan dan diwariskan.

Pemerintah melakukan perlindungan terhadap perusahaan atau pelaku usaha yang mengeluarkan merek, jika ditinjau lebih dalam, dalam ayat tiga yang menyebutkan bahwa wadah yang digunakan haruslah wadah yang tidak bermerek, hal ini sejalan dengan hukum Islam yang menjelaskan bahwa merek merupakan salah satu buquq maliyyah (hak kekayaan) yang mendapat perlindungan hukum, seperti yang disebutkan dalam Fatwa MUI Nomor: 1/MUNAS VILMUL5/2005 
Tentang Perlindungan Hak Kekayaan Intelektual (HK).

Dalam hukum Islam Merek bagian dari hak milik pribadi, bukan hak milik umum. Hak milik pribadi merupakan hak milik syara' pada individu untuk memanfaatkan sesuatu, baik berupa benda maupun jasa. Setiap bentuk pelanggaran terhadap HKI, termasuk namun tidak terbatas pada menggunakan, mengungkapkan, membuat, memakai, menjual, mengimpor, mengekspor, mengedarkan, menyerahkan, menyediakan, mengumumkan, memperbanyak, menjiplak, memalsu, membajak HKI milik orang lain secara tanpa hak merupakan kedzaliman dan hukumnya adalah tidak boleh.

Untuk menghindari berbagai bentuk kedzaliman maka perlu diadakannya proses pengawasan, dalam hal ini yang mempunyai kewajiban menurut peraturan yang ada adalah Dinas Perindustrian dan Perdagangan, jika dilihat dari mashlahah mursalah maka proses pengawasan tersebut dilakukan sebab proses pengawasan tersebut menyangkut hal yang berhubungan dengan maslahat orang banyak

Dengan menggunakan teori maslahah mursalah maka ketentuan ini bertujuan untuk melindungi hak sebagai konsumen yang perlu diperhatikan bagi seorang produsen. Imam asy-Syatibi menjelaskan tentang maslahah dan mafsadah di dunia, lebih memilih untuk mengembalikan pada pandangan umum, ketika sisi perbuatan memiliki sisi maslahat lebih kuat maka ia secara umum dapat dianggap sebagai maslahah, demikian sebaliknya karena dia berpendapat bahwa dunia adalah tempat berkumpulnya maslahah dan mafsadah sebagai tujuan umat manusia.

Pengawasan terhadap pelaku usaha pengisian air isi ulang merupakan hak dari pemilik merek suatu galon tertentu, karena hal ini tidak lepas dari pemakaian galon bermerek dari perusahaan atau pemilih hak merek. Hal itu diatur dalam Keputusan Menteri Perindustrian dan Perdagangan No. 651/MPP/10/2004 Tentang Persyaratan Teknis Depot Air Minum Isi Ulang dan Perdagangannya. Selain diatur dalam Kepmenperindag, pengawasan terhadap pengisian galon bermerek juga diatur dalam hukum Islam. Dalam Hukum Islam HKI dipandang sebagai salah satu huquq maliyyah (hak kekayaan) yang mendapat perlindungan hukum (mashun) sebagaimana mal (kekayaan)

Melakukan pengawasan merupakan wujud dari taat terhadap peraturan pemimpin/pemerintah. Taat artinya tunduk, baik kepada Allah SWT, pemerintah, orang tua dan lain-lain, tidak berlaku curang, dan setia. Taat pada aturan adalah sikap tunduk kepada tindakan atau perbuatan yang telah diatur baik oleh Allah SWT, nabi, pemimpin, atau yang lainnya. Aturan dibuat dengan maksud agar terjadi ketertiban dan ketentraman. Oleh karena itu, wajib hukumnya mentaati aturan yang berlaku. Taat kepada Allah SWT adalah hal yang paling utama, 
namun juga harus taat terhadap peraturan pemimpin, selama tidak bertentangan dengan aturan agama.

Peranan para pemimpin sangatlah penting. Sebuah institusi dari terkecil sampai pada suatu negara sebagai institusi terbesar, tidak akan stabil tanpa adanya pemimpin. Tanpa adanya seorang pemimpin dalam sebuah negara, tentu negara tersebut akan menjadi lemah dan mudah terombang-ambing oleh kekuatan luar. Oleh karena itu, Islam memerintahkan umatnya untuk taat kepada pemimpin karena dengan ketaatan rakyat kepada pemimpin (selama tidak melakukan maksiat), akan terciptalah keamanan dan ketertiban serta kemakmuran.

Maka dalam hal ini warga negara diwajibkan untuk taat terhadap peraturan peraturan yang telah dibuat oleh pemerintah, sebab peraturan yang ada bertujuan untuk kemaslahatan bersama, Dalam Alquran dijelaskan:

Firman Allah SWT dalam QS. An-Nisa'(4): 59:

"Hai orang-orangyang beriman, taatilah Allah dan taatilah Rasul (Nya), dan ulil amri di antara kamu. Kemudian jika kamu berlainan pendapat tentang sesuatu, maka kembalikanlah ia kepada Allah (Al Qur'an) dan Rasul (sunnahnya), jika kamu benar-benar beriman kepada Allah dan hari kemudian. Yang demikian itu lebih utama (bagimu) dan lebih baik akibatnya."(QS. An-Nisa'(4): 59)

Hadits dari Ubadah bin Shamit r.a, Rosulullah SAW bersabda:

"Kami membaiat Rasulullah SAW berjanji setia untuk mendengar dan taat (kepada pemerintah), baik ketika kami semangat maupun ketika tidak kami sukai. Dan kami dilarang untuk memberontak dari pemimpin yang sah." (HR. Bukhari 7199 dan Muslim 1709).

Ayat Al-Qur'an dan hadits diatas merupakan perintah untuk taat kepada pemimpin/pemerintah. Dalam hal penerapan pengawasan, Disperindag tidak melaksanakan peraturan pemerintah yang mewajibkan untuk melakukan pengawasan terhadap pelaku usaha depot air minum isi ulang . Dapat dikatakan bahwa Disperindag tidak taat terhadap peratutan pemimpin/pemerintah. Dalam Islam seperti halnya dengan seorang hamba yang tidak taat terhadap perintah Allah SWT.

\section{Simpulan}

Berdasarkan hasil kajian pengawasan oleh Disperindag Kota Malang terhadap pelaku usaha isi ulang air galon, maka peran Diperindag diperlukan dalam pengawasan tersebut. Sebagaimana pemerintah telah mengatur pengawasan melalui Keputusan Menteri Perindustrian dan Perdagangan No.651/MPP/10/2004 Tentang Persyaratan Teknis Depot Air Minum Isi Ulang dan Perdagangannya, tentunya 
menjadi tanggung jawab dan tugas Disperindag untuk melakukan pengawsan. Untuk melindungi konsumen terkait kwalitas air dan melindungi pemilik merek galon air, maka demi kemaslahatan diperlukan peran Disperindag Kota Malang secara aktif melakukan pengawasan, meskipun dengan keterbatasan sumber daya manusia yang tersedia. Berdasarkan Peraturan Daerah Kota Malang No. 56 Tahun 2008 Tentang Uraian Tugas Pokok, Fungsi dan Tata Kerja Dinas Perindustrian dan Perdagangan Pemerintah Kota Malang, maka menjadi tugas Disperindag untuk melakukan pengawasan terhadap galon isi ulang di Kota Malang.

\section{Daftar Pustaka}

Haroen, Nasrun. Ushul Figh 1. Cet. 2, Jakarta: Logos Wacana Ilmu. 1997.

Hidayah, Khoirul. Hukum HKI(Hak Kekayaan Intelektual) di Indonesia Kajian Undang-undang \& Integrasi Islam. Cet. 2. Malang: UIN-Maliki Press. 2013.

Manullang, M. Dasar-Dasar Manajemen. Yogyakarta: UGM University Press, 2005.

Purwadi, Ari. Telaah Singkat Tentang Undang-Undang Perlindungan Konsumen, Jurnal Hukum dan Keadilan, vol. 3, No. 3. 2000: 116-126.

Tim Penyusun. Pedoman Penulisan Karya Ilmiah Fakultas Syariah. Malang: UIN Press. 2013.

Santoso, Budi. Pengantar HKI dan Audit HKI untuk Perusahaan. Semarang: Pustaka Magister. 2009.

Saragih. Sistem Pengawasan dalam Organisasi. Jakarta: Rajawali Press. 1982

Sujatmo. Aspek-Aspek Pengawasan. Jakarta: Ghalia Indonesia. 1999.

Sujatmo. Beberapa Pengertian Tentang Pengawasan. Jakarta : Ghalia Indonesia, 1983.

Victor M. Situmorang, Jusuf Juhir, Aspek hukum pengawasan melekat dalam lingkungan aparaturpemerintah. Jakarta : Rineka Cipta, 1994.Barkatullah, Abdul Halim. Hak-Hak Konsumen. Bandung: Nusa Media. 2010.

Zahroh, Luluk Atirotu. AHKAM Jurnal Hukum Islam, Volume 08, Nomor 01, Juli 2006, Rekontruksi Metode Fiqih Hubungan Antar Agama, Majelis Syuro Muslimin Indonesia (Kajian Fiqih Siyasah), Jurusan Syariah, Sekolah Tinggi Agama Islam Negeri Tulungagung. 